\title{
Catheter-Related Infection
}

National Cancer Institute

\section{Source}

National Cancer Institute. Catheter-Related Infection. NCI Thesaurus. Code C78232.

An infection that arises secondary to catheter use. 